\title{
Faith-based agency and theological education: A failed opportunity?
}

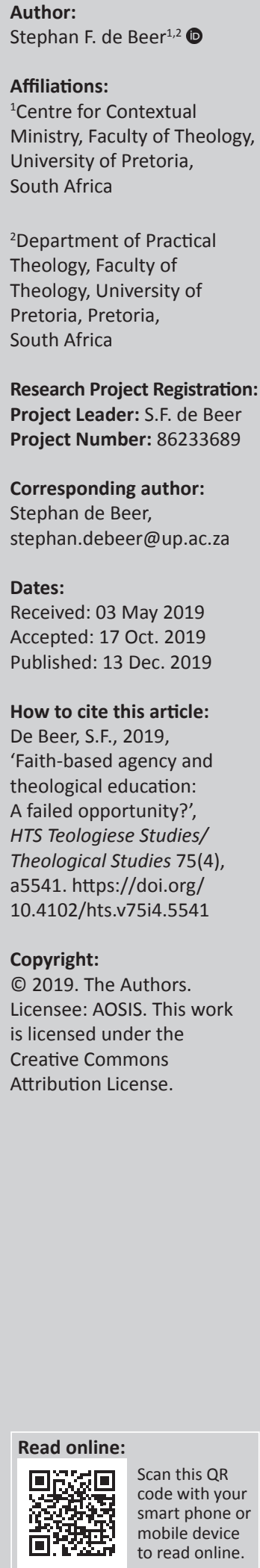

After attending to shifts in the landscape of theological education at a public university in South Africa, this article explores the re-imagination of theological education as fostering faithbased agency. With reference to the (potential) role faith-based organisations play in response to developmental challenges in local communities, it then suggests a deliberate retrieval of faith-based sources - locatedness, voices, assets, agency and formation - in liberating theological education. It concludes with concrete curriculum recommendations for consideration.

Keywords: faith-based agency; theological education; praxis-methodology; socio-ecclesial assets; epistemologies of liberation.

\section{Introduction}

Unless theological education becomes deliberate about (1) fostering agency for faith-based action that goes beyond the local congregation, and (2) retrieving the latent assets of theological wisdom, experiential knowledge and grassroots embeddedness, to be found in many grassroots faith-based organisations, this will be a massive failed opportunity.

In this article, the author considers the shifting landscape of theology - and students studying theology - at public universities in South Africa, the proliferation of faith-based organisations engaging in developmental challenges and the striking disconnect between these two worlds. The author challenges an assumption that theological education in our public universities is, or should be, to prepare (Protestant) pastors for church ministry, proposing, rather, a more deliberate intentionality about faith-based praxis that goes beyond local congregation.

\section{Shifts in theological education post-1994}

The face of theological education in South Africa has changed post-1994. I roughly distinguish between structural or demographic changes, ecclesial changes and the imperative (or rhetoric) of transformation.

In his article, 'Theology and the post-apartheid university: Mapping discourses, interrogating transformation', Venter (2016) traces shifting discourses and trends in theological education in South Africa. Venter's (2016) first map is 'facing the irony' of theology being marginalised at public universities, generally, in spite of religious and theological underpinnings of a modern university. He speaks of smaller number of students and less profits that reduce the institutional validity of theology. Even if faculties of theology exist, there is often a perception that it is only at the gracious behest of the powers that have to justify their reason for existence.

\section{Structural, demographic or ecclesial shifts}

At a large institution such as the University of South Africa (UNISA), what was once a large and independent faculty of theology, today it has turned into three departments within larger schools, each consisting of a number of disciplines. ${ }^{1}$

At previous Afrikaans institutions such as the University of Pretoria, University of Stellenbosch, University of Bloemfontein and University of Northwest, ironically, little has changed structurally, as their status of having independent faculties is continuing. At the University of Pretoria, the Faculty of Theology A of the Nederdutch Reformed Church and the Faculty of Theology B of the

1.The three departments at UNISA are the Department of Biblical and Ancient Studies (UNIISA 2017), the Department of Christian Spirituality, Church History and Missiology (UNISA 2018) and the Department of Philosophy, Practical and Systematic Theology (UNISA 2019).

Note: Faith-Based Organisations, sub-edited by Nadine Bowers du Toit (Stellenbosch University), Vhumani Magezi (North-West University) and Elisabet le Roux (Stellenbosch University). 
Dutch Reformed Church have merged into a single faculty, today known as a multi-church faculty (cf. Wethmar 2001:421-425). It should be noted that at both the University of Pretoria (UP 2019) and the University of the Free State (UFS 2000-2019), the faculties changed their names to the Faculty of Theology and Religion, now endeavouring to offer broader options to prospective students.

At the University of Pretoria, the student body transitioned from being all-white in the early 1990s to being very diverse today; from being almost completely reformed to being ecumenical (Wethmar 2001:425-427); from a narrow ecclesialbased constituency to a broader faith-based constituency; from theology only to a Faculty of Theology and Religion (Buitendag 2016). Demographically and ecclesially, these represent huge shifts. The author refers to students' reasons for studying theology - also marking a shift in the student body - in the next section of this article.

In a specific module I teach on engaging communities, I asked students a number of questions to be able to locate who they were, why they studied theology in the first place, and to what possible end. This represents one class in our Faculty of Theology and Religion, but is representative of what has occurred in recent years in the whole faculty. ${ }^{2}$

In this one class, 13 of the 31 respondents were women, 17 were men, and 1 person did not state gender. Eighteen students were black and 12 were white. Twenty-five belonged to churches; one said she 'kinda/sorta' belongs; and four indicated that they did not.

Denominationally, it was interesting to note a rather drastic shift from whom this faculty traditionally catered to, with 12 students coming from the broader Reformed tradition (mostly white students; 40\%); 37\% came from Charismatic, Pentecostal, non-denominational or Methodist churches, and 3 indicated 'other' as their affiliation. Venter (2016), however, asserts that student bodies might have changed rather drastically, such as the example of Faculty of Theology and Religion at the University of Pretoria; and yet, '(s)ome churches, especially those of the Reformed orientation, still deem that the faculties are "theirs" and that church oversight committees have a valid oversight base' (n.d.).

This could, of course, be dismissed as mere nostalgia for a past era. But, at a deeper level, it could also be a reflection of an institutional or ecclesial inability of such churches to acknowledge a completely new reality - political, institutional and also ecumenical. In some cases, ever so subtly, one can trace a paternalistic sense of a perceived moral responsibility to serve as custodians of 'good theologies' - when, in fact, what we speak of is 'our theologies', which often, in the heat

2.This information was gathered with the verbal consent of 2 nd year students of theology at the University of Pretoria, at the onset of their Community Engagement module, for which I was the lecture. This formed part of their orientation to the module, and my own orientation to the class in front of me. The purpose was to assess the diversity of the class and the intended future careers that students were considering, in order to align course content to the contexts students were from, or students were envisaging in the future. of radical socio-political changes in our country proved to be impotent.

Running glibly over these issues, without reflecting deeply on their implications for theological education, if not critically engaged, will have grave consequences.

Such consequences might include failing to appreciate and respect adequately the diversity of students in our classrooms, with their own unique existential and ecclesial experiences. It will fail to draw from the diversity of Christian traditions (cf. Lombaard 2016) that should inform our theological engagement at public universities, and particularly those for whom our universities traditionally had no time or space. It would also continue to exclude some who might want to contribute constructively in shaping theological knowledge, but cannot see themselves - currently - reflected in the body of knowledge (re)presented. It also, as the bias of this article, would propose, exclude the deep well of resource available in faith-based organisations and practices in cities and towns all over the country, simply because we are not deliberate about this vital, potentially life-giving, asset.

Sometimes it might be that we do not hear ourselves speak. We acknowledge some of the shifts, but then still go on to define ourselves rather narrowly. One person spoke of us now being a Protestant faculty, departing in his own mind from our Reformed constraints. Yet, at a public university in South Africa, this too cannot happen. At the very least it could be seen as an innocent exclusion. But, in practice, it would be contentious, dangerously exclusivist and downright improper to again clothe ourselves in such a narrow cloak.

\section{The imperative of transformation}

Apart from structural, demographic and ecclesial shifts, South African institutions also face the imperative of transformation - both institutional and curricular. Venter (2016) speaks about an embrace of transformation in postapartheid South Africa as a second map. With reference to Landman (2013), he mentions people who previously had no access even to study at universities in South Africa who are now on staff and even deans of faculties of theology:

Over the past thirty years, theological education in South Africa has developed from being, white, male, and/or denominational to liberational, ecumenical and inclusive of gender, race of belief. (p. 239)

Venter (2016) notes similar shifts, but it is questionable whether the transformation has been as deep and wide as Landman (2013) suggests at the four public universities where theology still has its own independent faculties. Although, at some levels, important shifts and changes took place, especially with regard to the face of student bodies, whether one can speak of the shifts at the four public universities to be liberational, deliberately ecumenical, or even authentically inclusive, needs much closer scrutiny (which is not the purpose of this article). 
Demographically and ecclesially, it is more inclusive than before because there is open access. Student bodies have diversified and have become more ecumenical. But the diversity of knowledge and experience in classrooms, and the ecumenical richness they represent, is not necessarily optimally invited to help shape new knowledge. In all these faculties, a Reformed orientation to theological education still dominates, shaping curricular content, without content being shaped similarly by the ecumenical body present in the classroom.

As for a liberationist shift, such should be grounded by exercising clear options for the poor and social justice in our curricula and embodied commitments. The mere fact that language to this effect might sometimes appear in mission statements, does not make it liberationist. The largely suburban locations of theological education, for a start, dictate pedagogical possibilities away from where the majority of South Africa's people are to be found. Our theologies, by and large, simply do not embody liberationist engagement with communities.

A more precise question is whether the 'imperative of transformation' is only an expression of institutional bureaucracy, without it being adequately and critically theorised from a theological perspective. Are we 'playing the game' of numbers and tick boxing, or have we done our own critical theological reflection on the kind of transformation required, from below and from within, and not only as a dictate from university executives?

Although traces of transformation occur in theological education, one should indeed ask: Whose transformation? Transformation on whose terms? And, how far curricula, pedagogical approaches and institutional cultures of faculties have been able to transform, not because of outward pressures but because of clear, inner conviction of theology as liberation/transformation?

Venter (2016), in mapping 10 major discourses in the landscape of theological education in South Africa today, provides 'an interpretation of transformation for theology that emphasises its multi-layered nature'.

Our transformational engagement indeed needs to include the transformation of university, and the transformation of theological education, in the face of South Africa's on-going transformational challenges.

At a much deeper level, Venter $(2013,2016)$ speaks of this as the challenge of 'epistemological transformation' with questions about 'whose knowledge is transmitted, for whom is knowledge generated and to what effect'. The author raised similar issues in an article titled 'Whose knowledges shape our city?' (De Beer 2014), suggesting that untransformed epistemologies perpetuate exclusivist cities, shaped 'from above' by people not experiencing the hardships and vulnerabilities of the majority of urban dwellers.
Much has been done to put cloaks of 'transformation' over deeply entrenched ways of doing theology, without adequate and in-depth self-reflection as to our own epistemological baggage. Shifts in theological schools at public universities post-1994 necessitate such an in-depth work.

\section{New expressions of contextual theology}

The third map located by Venter (2016) is the challenge of finding and articulating 'a new contextual theology'. This is indeed what lies behind this article. The author does not intend here to articulate a new contextual theology, but definitely suggests that the kind of questions we ask, helps give expression of new forms of contextual theology being done at public universities: Where and how do we locate our theologies? Which contexts do we write from, for and with? Who are our theological partners, interlocutors and guides? Who do we educate theologically? What are our theological methods? And, for what purpose?

Some of the critical transformational shifts required in our theological education could be facilitated by proponents practising diverse forms of contextual theology. Venter (2016) strangely refers only to those belonging to a former era, and fails to acknowledge and retrieve some of the current contextual voices ${ }^{3}$ teaching in various theological and religious faculties or departments in South Africa. This might be mere oversight, but it could also be a symptom of what he so ably argues against, namely the way in which dominants power constructs tend to marginalise alternative discourses that place excluded voices of people and places at centre stage.

New expressions of contextual theologies are required not only in terms of theology's deliberate connectedness to local and specific challenges of communities and places but also in terms of the theological methods inherent in contextual theological engagement.

Lombaard (2016) makes a point that, for all of its diversity, a 'defining characteristic of theological education' everywhere remains the importance of 'specificity', 'locality' and 'contextuality', as the Christian community receives 'the greater worlds' - what occurs as global trends in the Christian community internationally and ecumenically - in the local, 'in a small circle' and 'on-the-spot'. Whereas our theologies need to be connected globally and historically, but if it fails to be life-affirming in relation to very local challenges, it forfeits its right to exist.

The challenge of epistemological transformation also has to do with theological method. Contextual theologies depart

3 Various theologians currently active at South African universities do theology contextully-whether in the form of black, liberation, feminist or other theologies cond their works need to be acknow and their works need to be acknowledged in reconsidening the futures of theologica education at public universities. A few examples include Bowers-Du Toit (2018) Buffel (2013, 2017); Hankela (2014a, 2014b); Nel (2011, 2016) and Vellem (2007 2015a, 2015b, 2015c). 
from linear theologising in which universal theological 'truths' are taught, which are supposedly having universal applicability in all contexts. Contextual theologies insist, instead, on action--reflection approaches, such as the praxisapproach of Gutierrez (1983, 1990), Boff and Boff (1986) or Pilario (2005), the praxis-cycle of Holland and Henriot (1983), or the See-Judge-Act methodology of Cardinal Cardijn (cf. Sands 2018). These methodological approaches integrate live faith, deep contextual immersion and analysis, critical theological reflection, and planning for action as key elements in the process of doing theology. They are cyclical in nature and acknowledge the validity of personal experiences, ministry practices and context analysis as sources of theologising that need to help inform our theological reflection and imagination. Contextual theological approaches are doing theology with a strong emphasis on holistic liberation and more fundamental societal transformation.

Most theological curricula at public universities in South Africa are not standing in the tradition of a prophetic theological approach, or, as per the bias of this article, the praxis-approach. Some exceptions included a number of theologians at the University of KwaZulu-Natal (UKZN) who were deeply committed to doing theology contextually, and were often publishing through Cluster Publications (https://clusterpublications.com/), as were some theologians at the UNISA. The School of Theology at UKZN, now known as the School of Religion, Philosophy and Classics, was committed to 'provide forms of theological education that would equip African Christians to engage with their context, within a prophetic theological framework' (West 2013:920). This commitment was deeply shaped by the content of the Kairos Document The Kairos Theologians (1986) that was characterised by doing theology from below, regarding the poor as primary interlocutors of theological discernment and using a praxis-approach for doing theology (cf. Haddad 2016).

Balcomb (2015:10) argued that such contextual theological reflection should not restrict itself only to the socio-political changes, and secondly, should not only consider the work of theologians at schools of theology, but should give special consideration to 'the work of ordinary people' (Balcomb 2015:10). In a number of programmes offered at the UKZN, his critique is taken to heart, connecting deeply with the issues of gender and HIV/AIDS, and creating hospitable spaces in which ordinary people of faith, activists, and ordinary citizens connect in conversation with theologians.

\footnotetext{
4.Examples at the UKZN include the work of West $(1993,1995,1999)$ on contextua Bible study, African Biblical hermeneutics and liberation theology; the Theology and Development Programme initiated by Cochrane and later directed by De Gruch and Haddad (cf. Haddad 2016); the work of the Ujamaa Centre (UKZN 2019a) hosting conversations between Biblical theologians, local communities of the poo and organic intellectuals; and, more recently, the work of Charlene van der Walt and organic intellectuals; and, more recently, the work of Charlene van der Walt (UKZN 2019b) doing contextual and intercultural Bible readings, feminist and quee interpretation of the Bible and exploring the intersection between gender, health and theology as well as sexuality and queer studies. At the UNISA, theologian standing in the prophetic or liberationist tradition included Botha (2015), Klippies (JNJ) Kritzinger (1991), Simon Maimela (Maimela \& Hopkins 2017) and Mofokeng (1983) with a new generation of theologians in the same tradition having emerged at UNISA in recent years.
}

The contextual rigour, dynamism and engagement with reallife struggles represented by such theologies are sorely missed, and need to be revived in our time. New expressions of contextual theologies are required that could help foster in students of theology an alternative imagination of hope, dignity, justice and flourishing (cf. Venter 2016), desperately needed today in volatile and confusing global and South African contexts. Students' lived experiences in itself should be embraced as valid and important sources of theologising, if invited into conversation with theoretical knowledge constructs, with a view of fostering potent alternative imaginations.

As part of this journey, Venter (2016) cautions, not only should theology help shape a social ethic that contributes to society's greater challenges, which Venter reckons would be reductionist, but our theologies also need to continue asking questions about 'transcendence' and 'the Sacred' in the face of such challenges. What, namely, is the unique witness of theology in the face of life's 'big questions' (Venter 2013)?

\section{Fostering faith-based agency: Re-imagining theological education}

There are a number of questions that run like threads through this article: What is the purpose of theological education? Who do we educate? How do we educate?, and with whom? I am not going to address each of these questions on their own, but they are hovering in the background, begging to be accounted for responsibly. At the core of my argument is a twofold urge: To foster faith-based agency in theological education, which goes way beyond preparing clergy for congregational ministry, although it might include that, and in doing so, to retrieve faith-based agency in local communities.

With the shifts that had occurred in past two decades, sometimes intended and sometimes unintended, new challenges are being faced by faculties of theology, and the responsiveness of curriculum development to such challenges still seems rather tentative. It is important to question afresh the actual purpose of theological education at public universities. Those entrusted with the task of shaping theological education are we, products of ecclesial histories and models that sometimes leave one ill-equipped for some of society's greatest challenges. It would be important to address this challenge by both diversifying those responsible to teach in faculties of theology and shaping the collaborations that could help enable liberating theological education.

For theology not to be an irrelevant and sterile intellectual religious discipline, with little concrete bearing on society's biggest challenges, our curricula need to create and mediate the kinds of bridges between theology as discipline, faithbased agency and societal transformation. The author proposes this to be at the heart of theological education in South Africa today. 


\section{Who is in the class?}

This assertion is based on a reading of the shifting student bodies in our institutions. Out of 31 respondents in secondyear theology class, only 12 students specifically indicated that they study theology because they want to become ministers of the Word. These 12 respondents included two vaguer indications such as wanting to become a preacher or teacher. Five respondents indicated a desire to become lecturer or teacher of religious studies. Thirteen respondents (43\% students) cover a range of different future possibilities: 2 = missionaries; 3 = to help people (without qualifying what they mean or what format such help would take); 1 = wanting to help people back to God; $1=$ marriage counsellor; $1=$ spiritual psychologist; 1 = spiritual coach; 1 = political work; $1=$ ministry with schools / sport people; 1 = preaching for the elderly. One respondent was studying theology 'for credibility', and another 'to inspire people with theology'. One respondent indicated 'undecided yet'.

If only $40 \%$ of respondents are preparing themselves theologically with an intention to become ordained ministers, and if the majority of respondents indicate an intention to do faith-based work in some form or the other - counselling, coaching, political work, helping others - yet not necessarily as minister of a local congregation, how does this challenge our models of theological education?

From this sample - and it should be tested with more students in other years of study and other faculties of theology elsewhere in South Africa - people study theology to receive a broad theological and ethical framework which might or might not be specific to the actual vocation they desire. If our theological education is still mainly shaped by the needs of formal member churches, although in the case of Pretoria only $40 \%$ of the class comprises such second year students, whilst $47 \%$ of the class come from churches not formally members of the faculty, and $13 \%$ stated no church affiliation, we might need to revisit our basic educational premises.

It is my contention that our theological education is still largely shaped to equip white members of Reformed churches, and if this is the case, we do an injustice to other $60 \%$ of students.

\section{Theology as fostering faith-based agency for the common good and flourishing societies}

Of course, not all theological students attend public universities. Some churches prefer ecclesiastical seminaries, non-denominational seminaries or church-oriented universities (Venter 2016; referring to Brown 1994). In this article, however, I focus on the theological offering at public universities, and specifically those four universities that still have independent Faculty of Theology.

Venter (2016) asks this pertinent and crucial question: 'Does the knowledge, transmitted and generated, serve public good or narrow sectional interests?' Venter reckons that the university, Faculty of Theology and churches should explore this question with greater rigour.

If the majority of students of theology still indicates a theological commitment rooted in a certain faith or religious persuasion, such as the case of our Faculty of Theology, whilst at the same time they are no longer exercising a clear desire or option to become ministers of local churches - in fact, $60 \%$ students are not - it should provide a clue as to what do we prepare people for, and how we should be going about doing it. We will fail the future of theology in our country, our students and ourselves if we serve narrow sectional interests over common or public good.

Venter (2016) offers his own suggestion, which this author agrees with, namely that 'the well-being of the common good becomes a primary referent' for the way in which we do theological education. In the introduction to this section, the author contemplated theological curricula as a bridge between theology as discipline, faith-based agency and societal transformation.

Can theology as a discipline foster the kind of faith-based agency that is required for societal transformation? How would we have to re-imagine and reconstruct our theological curricula if this has to become the central tenet of our contribution (cf. De Gruchy 2003; Haddad 2016)?

I wonder if it would be an unfair assessment of our current theological education to suggest that we often leave a void, unable to shape alternative constructs and animate liberatingtransformative practices with the same rigorous discipline of deconstructing dominant and exploitative constructs and practices.

Not only should our theological interrogation major on deconstructing dominant or oppressive discourses and practices, developing critical competencies amongst students but with the same rigour tools need to be provided and spaces opened up to provoke bold new imaginations, representing radical alternatives to a status quo that does not work.

Firstly, one would have to develop a clearer theological imagination for the content and vision of such social transformation. This is not a space for a lengthy theological treatise on that, except to, very tentatively, propose that it needs to be focused on how faith-based agency could contribute to affirm, enhance and protect the common good; to resist, subvert and overthrow all that seeks to deplete the common good in favour of narrow self-interest; and in doing both, to work tirelessly for flourishing humanity, local communities and societies at large.

Secondly, one would have to develop a clearer imagination of how theological education can contribute to such a societal vision: How can one learn from the best of faith and social innovation in the past and the present to build a faith-based 
agency - ownership, knowledge, skills and courage - for the present and the future.

In practical terms, embracing a clear imagination for fostering faith-based agency could be translated in the design of programmes that, 'for example ... opens career options way beyond ecclesiastical vocations' (Lombaard 2016).

In conversation with current students of Faculty of Theology and Religion at the University of Pretoria - those not focusing on becoming ministers or pastors of churches - my sense is that they already study theology hoping that it could prepare them to find vocations beyond narrow ecclesiastical boundaries: in faith-based or non-profit settings, social enterprises, ministries of healing and counselling, or somewhere in public sector. ${ }^{5}$ However, my contention is that current theological curricula then fail them dismally, as our offering seems to still centre around the ecclesiastical requirements of the smaller percentage of students in our theological institutions. This is to perpetuate new injustices and exclusions.

\section{Reclaiming the primacy of diaconate}

If fostering faith-based agency for the common good and flourishing societies is indeed the central focus of theological education, then the author would strongly argue for reclaiming the primacy of diaconate, in the sense in which Fuchs (1993) uses it. To Fuchs, the diaconate is expressed in the love (mercy and justice) and freedom (individual and societal) mediated by the church. The impact of the church, for Fuchs, is to be determined by how they are experienced as 'healing and solidarising communities'.

The form of faith-based agency in a fractured society like ours - marked by gross inequalities, brutal violence and historical and new trauma - should probably be that of holistic pastoral diaconate, or diaconal pastorate, integrating worship, care, healing and justice. The centrality of an integral diaconate that serves communities through bringing together these four critical elements has been lost in the church's ascension to power and descent into institutionalism.

Ecclesial bureaucracies are stifling spontaneous movements of deep servanthood that spans personal, communal and systemic spheres, and is creative in responding to societal fractures. Instead, faith-based agency should enable students of theology to find themselves meaningfully in local congregational settings, community development organisations, advocacy and justice organisations, global social movements, social enterprises or public sector, evercommitted to mediate wholeness in society, and informed and sustained by deep faith-based agency would enable the mediation of deep love and freedom through 'healing and solidarising communities' (Fuchs 1993).

5. Naidoo $(2015: 174)$ reflects on recent shifts in practical theology, beyond a narrow ecclesiastical, clerical or therapeutic paradigm, to a more 'hermeneutical model of ecclesiastical, clerical or therapeutic paradigm, to a more 'hermeneutical model of
pastoral engagement', empowering reflective practitioners able to reflect whilst pastoral engagement', empowering reflective practitioners able
engaging in practices beyond the confines of a local congregation.
This would require very innovative and bold curricular development, both exposing students of theology to broader vocational opportunities and equipping them accordingly, whilst also considering diversified curricular options in order for students to be able to specialise in fields beyond congregational work. Large bodies of knowledge on faith-based community development or organisational development are, for example, only sporadically included in current curricula, which, contextually, is untenable. Good examples of diversified programmes exist elsewhere and engaging such programmes to gain knowledge, even in terms of institutional partnerships and knowledge-sharing, could be very beneficial ${ }^{6}$ to contextualised and diversified local theological curricula. These programmes are evidently shaped both around opening up diversified vocational imaginaries and possibilities for students of theology and responding to specific societal challenges. ${ }^{7}$

The current constraint, however, is that most of our theological education models are preparing people for congregation-based ministry, in rather a-contextual ways, instead of equipping students to be prepared for vocational engagement in a diversity of settings, which might include congregational work.

\section{Honouring students and communities: Diversified theological education}

Theological education in South Africa today needs to learn how to walk complex tightropes, simultaneously deeply honouring those who are in the class - with their respective stories, traditions, hopes, fears and aspirations - as well as deeply honouring our communities - both the faith communities represented in our faculties, the diverse communities that make up South African society and, with particular rigour, those communities still experiencing marginalisation from the systems and resources that make flourishing life a possibility.

Even if people prepare for congregational ministry, which a large percentage of students still do, then the question should be what kind of congregational ministry are we imagining and what kind of ministers are we preparing. In a country of vast inequality, are local churches, or faith-based organisations, only peddling narrow self-interests, or are they constructively contributing to the common good? How do we help shape liturgical, homiletic, diaconal, pastoral and other ecclesial functions in ways that can contribute to the common good of a flourishing society?

6.Institutions such as the VID Specialized University in Oslo (VID n.d.), the Northern Seminary (2019) in Illinois, the New York Theological Seminary (2012) in New York City, and Eastern University (2019) in Philadelphia, offer innovative Masters Programmes allowing students of theology to specialize in the areas as diverse as urban leadership, community development and social innovation, diaconate and Christian social practice, youth ministry religious leadership and administration, organisational development, value-based leadership and pastoral care and organisational develop counselling. Pittsburgh Theological Seminary (n.d.) has three very innovative join degree programmes in collaboration with three different Pittsburgh-based universities, namely theology and social work, theology and law and theology and
public policy and planning.

7.Consider the Theology and Development programme offered at the UKZN for almost 25 years (Haddad 2016). 
Congregational ministry that enables good interpretation and exposition of scriptures, void of robust contextual analysis, the ability to discern the signs of the times and the desire to develop responsive ministries of reconciliation and justice, are simply not good enough. These do not have to be mutually exclusive objectives but need to be integrated into contextually responsive curricula.

Perhaps, learning to walk this difficult tightrope would require a more dynamic, comprehensive and flexible curriculum, allowing at least some space for students to participate in building their own curriculum, in the direction of possible preferred vocational futures. Lombaard (2016) says it like this:

In a post-secularist cultural climate, theological education should therefore in content become more diverse and more rigorous, not only when measured to Church standards (although naturally always that too), but also when measured to cross-disciplinary standards.

It is to be considered whether a theological framework could be developed that provides a solid generic foundation whilst allowing for more elective possibilities, specialisations inside the main curriculum and specialised postgraduate options. This is indeed the case in a number of institutions but needs to be optimised everywhere both in the interest of responding appropriately to contextual challenges and also in terms of diversifying opportunities for vocational development and vocational futures for those who study theology. Instead of a narrow focus on church ministry, which was the emphasis of theology taught at the four public universities in question, contemporary society requires us to build much more robust faith-based agency that can be channelled into diverse vocational settings: congregational ministry; religious or theological education; community development or social entrepreneurship; ministries of advocacy or justice; public leadership or policy-making; peace-building or environmental care; child and youth ministry; ministries of healing and counselling, or creative combinations of all these.

Curriculum that is intentional about the above considerations, also needs to demonstrate clearly how these different competencies and vocational foci are all different yet critical elements in a theological imagination of ministry that is aimed at social transformation, the common good and flourishing society - indeed, the shalom of God.

\section{Retrieving faith-based sources in (liberating) theological education}

If theological education is to foster faith-based agency - in the broadest sense of the word (as described in the previous section) - it would be prudent of theological institutions to collaborate closely with a range of faith-based actors spanning the landscape of faith-based action. Such collaborations would enable a retrieval of faith-based sources as sources of knowledge and experience, without which theological education is much poorer in complex contemporary societies.

\section{Collaborative, trans-disciplinary theological engagements}

Lombaard (2016) argued very convincingly for such 'collaborative education and scholarship', when he stated the following:

Within the developing culture of post-secularism, it is to be expected that the Church be looked at afresh from what had earlier become quite extensively secularised circles. As one instance: in fields such a social and development work, the nomenclature of 'NGOs' (non-governmental organisations) is ever more routinely expanded to now also include 'FBOs' (faithbased organisations), thus acknowledging the (normal/ised) role of religion in community upliftment programmes.

Not only does Lombaard (2016) state these shifts in society but also stresses upon the resultant 'expectations on theological education' on both:

[T] he quality of the work done in this respect - nobody from the churches' side would want to feel looked down upon because of inferior training or abilities - and, no less, the nature of the training.

Lombaard (2016) makes a clear link between theological education and the non-profit and faith-based sector, as well as between other disciplines in general:

It will become increasingly necessary for theologians engaged in such cross-disciplinary work to deal meaningfully with concepts, insights and valid practices from the humanities ... as well as from other academic fields. (pp. 22-46)

In a similar way, Venter's (2016) fourth map for reading theological education in South Africa today, is '( $t$ )he public of theology: broadening allegiances'. As a critical reflection on past dispensation - in which it was 'tenable' to serve 'narrow nationalist purposes', for which theology provided 'religious sanction', with close proximity to specific Afrikaan churches of Reformed orientation (at formerly white Afrikaans universities) - it is untenable today, as it has been always, for theology at a public university to serve only such a narrow public.

More work should be done in the four faculties of theology to interrogate how best theology could and should serve university, church and society beyond narrow confessional theological paradigms (cf. Bosch 1991; Tracy 1981; Venter 2016; Wethmar 2001). In this regard, Venter (2016) imagines how a diversity of traditions could be invited and validated alongside each other as part of new and hospitable spaces for complementary but also contesting voices: 'The social and intellectual capacities of religious traditions could be interrogated, explored and imaginatively revisioned for the common good'.

This could, in Venter's (2016) mind, contribute to a required 'shift from a narrow community interest to a broader social application' in services of 'the common good'. It relocates the accountability of faculties of theology, now not anymore to the narrow interests of a very small percentage of the 
South African religious community, to the broadest possible constituency of people. The challenge is, how such broaderbased accountability - to the university, the ecumenical church in its diverse expressions, faith-based organisations, and society at large - could be inculcated, reflected in curricular commitments and actually measured.

Such collaborative forms of theological engagement - not only with different disciplines but also with practitioners and communities - require different approaches to knowledgegeneration and knowledge-sharing. In my mind, a certain understanding of trans-disciplinary engagement, embedded in a contextual theological paradigm, lends itself particularly well to collaborative theological engagement.

The Centre for Contextual Ministry at the University of Pretoria subscribes to Klein's (2001) definition of a transdisciplinary approach, as different disciplines collaborate with practitioners and communities to find solutions for real-life problems De Beer \& Van Niekerk (2017). In my mind, such a collaborative, trans-disciplinary approach to theological engagement, contextually rooted, could help integrate many of the considerations explored and proposed in this article. We have seen the potential of this approach in our research on street homelessness, land and housing rights, and social justice and reconciliation.

The real question is to explore creative ways of rethinking and reshaping curricula - not just in terms of content but even more in terms of epistemological, pedagogical and methodological approaches - to allow giving expression to more collaborative and trans-disciplinary ways of theological engagement.

\section{Retrieving faith-based sources}

I argue in this article that faith-based organisations could be one such partner in collaborative theological education, for obvious reasons.

Instead of continuing to drive academic agendas far away from local contexts, I argue for an appreciation of latent faithbased sources as possible sources to be employed in the services of liberating (our) theological education. In this section, I briefly focus only on five such - possibly liberating sources, namely location, contesting voices, assets, agency and formation. In speaking of faith-based sources, I include broader community-based sources, because for communities to practise agency and develop assets for their own transformation, it requires deep levels of faith (spiritual or religious faith and/or faith in the possibility of communities to help themselves).

The first distinctive source that faith-based organisations could offer to theological education, is location. It is important for theological education to revisit its locatedness, in a context marked by such stark socio-economic inequalities. If theological education is indeed an elitist enterprise, located on suburban campuses away from the struggles of local communities, students of theology are easily socialised into the impotency of displaced and a-political theologies.

In the Centre for Contextual Ministry, emphasis is placed on seeing the city as classroom, precisely to overcome the above challenge. We value the importance of local urban communities as classrooms of action, reflection, dialogue and research (cf. De Beer 2014), working closely with local faithbased communities in diverse urban contexts. City Seminary of New York (https://cityseminaryny.org), likewise, pioneered an innovative model of seminary education, turning pedagogy on its head by allowing the city to be the classroom and the people of local communities the teachers.

Faith-based and other local community-based organisations can offer spaces in which they are embedded as pedagogical spaces. Our theological educational models need to find new locations to ask difficult questions on doctrine, ethics, scripture, worship and mission, not in vacuum but in direct conversation with actual local struggles.

Relocating theological work should never be regarded as a gimmick but as a critical pedagogical tool. ${ }^{8}$

As theologians deal with the un-sanitised struggles of communities as well as the diverse ways in which communities seek to address their own struggles - often unorthodox and innovative - the chances of radicalising ${ }^{9}$ theological curricula become real, in both how it reflects theologically at the grassroots, with grassroots struggles as instruments of interlocution, and how it attends to the systemic root causes of much of society's contemporary pain and struggle.

Such an approach is a clear expression of doing theology contextually, with students learning how to do theology at the base, in vocabulary making sense in contexts, instead of peddling sterile constructs void of real substance.

The second source to be found with faith-based organisations is access to contesting, excluded or silenced voices, often not present or available in the corridors of theological faculties. (Not to say that there are not also contesting, excluded or silenced voices in theological faculties, of course.) Faith-based organisations, not always determined by narrow doctrinal interests but by a desire to serve the public good, are often in strong solidarity with particular populations characterised by deep vulnerability, be it street homeless communities, children living and working on the streets, commercial sex workers or people using harmful substances.

8.Dames (2019) speaks about this as 'a dangerous pedagogy of discomfort'.

9.I use the word here in reference to 'radix' (roots): I mean the grassroots spaces of local communities, and also the root causes of societal problems. 'Radicalised' in this sense implies that by doing theology at the grassroots, and by asking critical questions of the root causes of societal challenges, the chances of theologies becoming more radical - in the sense of dangerously unmasking powers of death and forging 'a new future of freedom and healing' (Dames 2019) - are becoming real. 
The voices, ambiguities, contradictions and contestations, experienced by some of these populations, often shape the theologies of faith-based organisations, as they go on journeys of solidarity together. Theological paradigm shifts occur with these organisations, even without them fully realising it because they do theology embedded in the lived realities and struggles of local communities 'on-the-spot' and 'on-therun'. They are often forced out of their so-called neutralities in order to take a stand.

The interlocutions that are possible in and with communities cannot be traded for sterile classroom experiences. The domesticated nature of theological conversations is to be penetrated by the messiness of local lived experiences, of contestation, violation and exclusion. This has the potential to enable difficult and courageous conversations that might not always be possible in suburban classrooms.

The third important source is that of community-based and faith-based assets (cf. De Gruchy 2003).

In the theological education of students, it is important to acknowledge both congregational and larger faith-based and community-based assets that sometimes serve to keep unravelling communities together, or, in other instances, facilitate more systemic transformation.

Such assets might include the values, skills and commitments of individuals in a community, institutional infrastructure (large and small institutions), community organisations and community networks, physical infrastructure, economic infrastructure (formal and informal) as well as the 'stories, culture and heritage of the community' (Kretzmann 2010).

This is a vital source of theological reflection as it helps students appreciate communities not only in terms of their deficiencies or pathologies but also in terms of their strengths, potentials and hopes. It equips students to see communities not through the lens of dominant and oppressive narratives but in ways that could foster hopeful and liberating alternative narratives (Kretzmann \& McKnight 1993).

Theologically speaking, this is, at the same time, an acknowledgment of the way in which God is revealed in local and contemporary histories (cf. Gutierrez 1983, 2012). It also provides concrete examples of transformative faithbased work as well as imaginaries of the kinds of ways in which students can engage the world around them.

Retrieving inherent assets becomes like an additional library not only of books but also of useful liturgies, worship material, organisational networks and good practices, tried and tested in the furnace of local community struggles.

The fourth source to be found with faith-based and community-based organisations is that of agency (cf. De Beer 2008:178-179; De Gruchy 2003). If theological education is to be re-imagined as the formation of faith-based agency, it makes much sense to connect curricular processes to people and places that have demonstrated agency in arresting societal decay and in facilitating personal, communal and systemic transformation.

'Agency', here, refers to the capacity of individuals and communities to act. It counters victims and dependency syndromes that have communities waiting for redemption on external agents. Instead, it appreciates and mobilises its own assets in ways that build capacity from within, slowly taking charge of its own future, building small projects and movements until it is strong enough to tackle larger systemic issues that keep communities down.

\section{According to De Beer (2008):}

Local government politics, the crisis in service delivery, ineffectual local councillors who are unable to foster participatory democratic processes, the paralysis of faith communities, the dictates of the market, the growing social exclusion of the poor, the inability of local people to shape their own future and that of their communities - all these leave us with a sense of powerlessness, of impending crisis. We can either wait passively for things to get better one day, or we can acknowledge our own active agency in history as communities of faith and as citizens of our city. (p. 178)

An appreciation for faith-based and community-based agency making deep change could contribute with theological students a fresh imagination of the kinds of transformative contributions churches and other faith-based organisations could make. It also serves as a sober reminder that systemic change is often not driven by public or private sector, as it is not always in their interest, and that restricting churches to be spiritual enclaves and faith-based organisations to relief services, are detrimental to communities, as it maintains the status quo. Instead, a theological imagination can be nurtured, connected to faith-based and community-based agency that holds as important the work of community and social transformation, spearheaded by communities themselves in ways that subvert the status quo of individualistic neoliberal capital, and forges communality and solidarity instead.

A last source to be retrieved, for the moment, is that of formation. Whereas formation is seen by some as something different from the intellectual pursuit of knowledge, or sharp distinctions are made between academic theology, on the one hand, and spiritual or ministry formation, on the other, this should now be challenged.

Conradie (1997) and Naidoo (2008) questioned whether intellectual scholarship should be prioritised in the way that it is. In the Faculty of Theology, University of Pretoria, students from formal partner churches have the benefit of an academic curriculum as well as what is known as churchown formation. But $60 \%$ of our students, not coming from formal partner churches, only benefit from the academic curriculum. And yet they are often desirous to serve in communities in ways that could make change, with very 
minimal preparation for doing so. Naidoo (2015:174-175) speaks of how many schools of theology are returning to or discovering an understanding of theological education as formation, emphasising the importance of personal formation in the act of doing theology and preparing for ministry.

This article strongly argues for formation to be integrated into the process of doing theology as an integral part of an epistemological shift that validates lived experiences, and being embedded in local contexts, as part of the generation of transforming knowledge and the construction of ministerial identity.

Once again, faith-based organisations can provide the locales in which theoretical work, practical ministry and personal formation could be fused, as a much more coherent whole offering to people preparing to make change in the world. In fact, I would go further, arguing that we do students a grave injustice if we provide them intellectual constructs void of deep, accompanied formation.

Where does all this leave the traditional theological educator at public institutions of formerly Afrikaans universities? It becomes challenging for the traditional theological educator, as his/ her role changes from expert to guide/facilitator/interpreter, creating new spaces in which students could try to make sense, in which conversations between the subject matter and contexts could take place continuously, and in which new kinds of creative fusions could take place between theory, practice and spirituality. Liberating theological education implies the on-going liberation of theological educator as well.

\section{Fostering faith-based agency: Curricular considerations}

I now try to weave together some of the threads arising from the previous sections, to make some concrete curricular recommendations, pertaining to both the overt and the hidden curriculum.

This brings me back to earlier questions: Where and how do we locate our theologies? Which contexts do we teach and write for, with and out of? Who are our theological partners, interlocutors and guides? Who do we educate theologically? What are our theological methods? And, for what purpose?

1. This article proposes an over-all purpose of theological education at public universities in South Africa today, a desire to contribute towards broad-based social transformation, flourishing communities and the common good. This would be required of theological curricula to have both a liberationist (deconstructive) (Gutierrez 2013a, 2013b; Hankela 2014c; Meylahn 2016) and transformational (reconstructive) (Graham 2011; Jennings 2011; Katongole 2010; Mugambi 1995; Volf 2015) dimensions - naming and unpacking that hinders social transformation, depletes the common good, and deals death to communities; and also that might contribute to social transformation, serve the common good and contribute to human, communal and societal flourishing.

2. For a theological imagination of social transformation, flourishing and the common good to not only remain an esoteric or intellectual pipe dream, but theological education should be revisited in terms of formation for faith-based agency (cf. De Gruchy 2003; Haddad 2016) beyond the narrow confines of congregational or ecclesiastical ministry. Such formation, it is proposed, starts with connecting theological education to the existing faith-based agency, active in local communities, whilst at the same time respecting the inherent agency of students, and ensuring that 'conditions ... be created and nurtured' (Venter 2016) that would enable students to practise their own agency boldly and freely.

What is meant here is not just agency in a generic sense but the agency - imagination, values, knowledge, skills and courage - to initiate, conceptualise, incubate and sustain faith-based actions in churches, outside churches, ecumenically, through social enterprises or in whichever format necessary:

3. The above won't be facilitated through isolationist theologising but could be mediated through collaborative, trans-disciplinary theological engagement. Venter (2016) speaks about disciplinary fragmentation as a modernist construct, hiding 'theology's ability to engage with complex social problems'. In this article a position is taken that assumes and proposes a trans-disciplinary approach, not as something to be intellectualised, but as a discipline to be discovered and honed as we practice it together, and with others.

4. The premises of this article are not neutral, proposing instead - new contextual theologies to be invited, constructed and embraced as we do theology with communities. It proposes contextual epistemologies of liberation, always considering silenced, exploited or excluded voices, engaging contesting voices, and allowing such voices to shape our theological imaginaries. According to Venter (2016): 'At the heart of the knowledge project is epistemic justice, which requires the inclusion of neglected voices and experiences of those conventionally ignored and suppressed'.

Black, liberation, womanist, feminist, queer and other such theological expressions would be rendered more central space in theological engagement as part of processes of decolonising and de-westernising curricula. This would be done deliberately as a way to allow silenced voices - and the voices they might be silencing to take centre stage in our theological engagements.

5. I would submit that praxis-methodologies, such as the praxis-approach of Holland and Henriot (1983), are able to integrate the above emphases rather well, in very concrete ways. It would require, however, that the curricular and pedagogical processes be aligned to the ethos and 'magic' of the cyclical praxis-approach, allowing for immersed theological engagement, 
critical socio-ecclesial analysis, imaginative theological reflection - in and with communities - and practical action, all in the direction of fostering faith-based agency.

This might not necessarily always mean a radical departure from current content but might require a reweaving of how different content pieces are offered: where, when, with whom and in relation to which other pieces.

6. The locatedness of theological education cannot be underemphasised. I strongly argue for the city as classroom which might be the actual city, or communities in which contestations present opportunities for creative theologising. Students of theology need to be deeply immersed in real-life contexts, there to read texts and formulate theological responses, and correctives, not in isolation from but in deep solidarity with local people and places.

Theological curricula need to find more creative ways of teaching and learning in contexts, allowing for text and context, theory and practice, to be in dynamic interaction with each other. Reading the Old Testament or the New Testament texts, for example, in local communities, with people whose voices are often silenced, might ask new questions of texts in mutually illuminating ways. A class in social or political ethics, taught in a neighbourhood where political processes threaten to displace vulnerable families, would bring the subject matter to life in ways that a classroom lecture won't be able to do on its own.

7. In shaping faith-based agency, students of theology should be introduced to socio-ecclesial and faith-based assets that serve to not only build resilient communities but also to facilitate community transformation at different levels.

Exposing students to such assets at an early stage would help foster the ability to think theologically about larger and specific societal challenges, to develop innovative theologies of stewardship considering God's resources in relation to socioeconomic disparities, and to draw from available assets in engaging communities.

Fostering faith-based agency, in my definition of it, would enable students of theology to learn from existing assets in communities, and to develop and contribute to building socio-ecclesial assets for community's well-being, in areas ranging from healthcare and housing to child and youth development, economic development, education, gender justice, and environmental care and justice.

8. Finally, the context we are in, and the nature of our student bodies, necessitate the integration of formation (cf. Naidoo 2015) into our theological curricula. To avoid the inequality of a situation where some students receive a more well-rounded theological education, doing academic work complemented by church-own ministerial formation, we have to consider the introduction of formational programmes to complement academic curriculum. This should not be seen as an optional addition to the curriculum but as part of an integrated offering.

If theological education is to contribute to the formation of faith-based agency, we have to consider how to create spaces in which people could grow personally, professionally, pastorally and politically in order to steward the mysteries of God's grace and justice in very complex situations. This is calling for more comprehensive formational work to be done as part of our theological education.

\section{Conclusion}

I suggest a reconsideration of theological curricula to mainstream the education of future leaders that could engage wisely, strategically and theologically in either starting, developing and sustaining faith-based organisations or engaging in public leadership roles, that bridge the gap between personal or ecclesial faith and the challenges of societal transformation and public life. I suggest that we currently fail faith-based organisations, our own students and ourselves by not recognising the priority of theological education inclusive of such a focus as well as the asset of FBOs in doing theological education.

Theological education that does not contribute concretely to social transformation, the common good and flourishing communities - through fostering faith-based agency however expressed - should be questioned fundamentally.

\section{Acknowledgements}

The author acknowledges the professional services of the language editor.

\section{Competing interests}

The author declares that no competing interests exist.

\section{Author(s) contributions}

I declare that I am the sole author of this research article.

\section{Ethical considerations}

This article followed all ethical standards for a research without direct contact with human or animal subjects

\section{Funding information}

This research received no specific grant from any funding agency in the public, commercial or not-for-profit sectors.

\section{Data availability statement}

Data sharing is not applicable as no new data were created or analysed in this study. 


\section{Disclaimer}

The views and opinions expressed in this article are that of author and not an official position of the University of Pretoria.

\section{References}

Balcomb, A.O., 2015, 'Theological education in South Africa and the epistemological divide: In search of the African habitus', Scriptura 114(1), 1-12. https://doi. org/10.7833/114-0-1039

Boff, L. \& Boff, C., 1986, Wat is theologie van de bevrijding?, Altoria, Averbode.

Bosch, D.J., 1991, 'The nature of theological education', Journal of Theology for Southern Africa 77, 3-17.

Botha, N., 2015, 'Community engagement as the organic link with the street: Creating a learning community between the academy and homeless people in Tshwane', HTS Teologiese Studies/Theological Studies 71(3), 1-9.

Bowers-Du Toit, N., 2018, 'Decolonising development? Re-claiming Biko and a black theology of liberation within the context of faith-based organisations in South Africa', Missionalia 46(1), 2018. https://doi.org/10.7832/46-1-219

Brown, E., 1994, 'Kweekskool teenoor teologiese fakulteit: Die ervaring van die Nederduitse Gereformeerde Kerk', Hervormde Teologiese Studies $50(1 \& 2)$ 68-94. https://doi.org/10.4102/hts.v50i1/2.2544

Buffel, O.A., 2013, 'Mission as liberation in socio-economic and political contexts: Towards contextual and liberating theology of mission in the context of migration and human dislocation', Missionalia 41(3), 239-255. https://doi.org/10/7832/40 3-38

Buffel, O.A., 2017, 'Black theology and the black experience in the midst of pain and suffering amidst poverty', Scriptura 116 (1), 1-14. https://doi.org/10.7833/115 $0-1298$

Buitendag, J., 2016, "“The idea of the university" and the "Pretoria model" apologia pro statu facultatis theologicae universitatis Pretoriensis ad secundum saeculum' HTS Teologiese Studies/Theological Studies 72(4), a4366. https://doi.org/10.4102/ hts.v72i4.4366

Conradie, E.M., 1997, 'An ABC in theological education', Nederduits Gereformeerde Teologiese Tydskrif 38(4), 349-361.

Dames, G.E., 2019, 'A dangerous pedagogy of discomfort: Redressing racism in theological education', HTS Teologiese Studies/Theological Studies 75(4), a5060, https://doi.org/10.4102/hts.v75i4.5060

De Beer, S., 2008, “Taking back our streets": Reading Steve Biko's black consciousness and the quest for true humanity on the streets of Tshwane', in C.W. Du Toit (ed.) The legacy of Stephen Bantu Biko: Theological challenges, Papers presented at the Forum for Religious Dialogue Symposium of the Research Institute for at the Forum for Religious Dialogue Symposium of the Research Institute for
Theology and Religion, University of South Africa, Pretoria, 23-24 August 2008, Theology and
pp. 169-197.

De Beer, S., 2014, 'Whose knowledges shape our city? Advancing a community-based urban praxis', De Jure 47(2), 218-230.

De Beer, S. \& Van Niekerk, A., 2017, 'Transforming curricula into the next century: Doing theology collaboratively with local communities', Verbum et Ecclesia 38(4), a1683. https://doi.org/10.4102/ve.v38i4.1683

De Gruchy, S., 2003, 'Theological education and social development: Politics, preferences and praxis in curriculum design', Missionalia 31(3), 451-466.

Eastern University, 2019, Majors and programmes, viewed 15 May 2019, from https:// www.eastern.edu/majors-and-programs.

Fuchs, O., 1993, God's people: Instruments of healing: The Diaconical dimension of the church, Peter Lang, Berlin.

Graham, E.L., 2011, 'Finding ourselves: Theology, place and human flourishing', in M. Higton, C. Rowland \& J. Law (eds.), Theology and human flourishing: Essays in honor of Timothy Gorringe, pp. 265-279, Cascade Books, Eugene, OR.

Gutierrez, G., 1983, The power of poor in history, Orbis Books, Maryknoll, NY.

Gutierrez, G., 1990, The truth shall make you free: Confrontations, Orbis Books, Maryknoll, NY.

Gutierrez, G., 2012, Christmas meditation: Christ's history, and ours, viewed 16 June 2019, from https://thevalueofsparrows.com/2012/12/29/christmas-meditationchrists-history-and-ours-by-gustavo-gutierrez/.

Gutierrez, G., 2013a, 'Conversion: A requirement for solidarity', in M. Griffin \& J. Weiss Block (eds.), In the company of the poor: Conversations with Dr Paul Farmer and Fr. Gustavo Gutiérrez, pp. 71-93, Orbis Books, Maryknoll, NY.

Gutierrez, G., 2013b, 'The option for the poor arises from faith in Christ', in M. Griffin \& J. Weiss Block (eds.), In the company of the poor: Conversations with Dr Paul Farmer and Fr. Gustavo Gutiérrez, pp. 147-159, Orbis Books, Maryknoll, NY.

Haddad, B., 2016, 'Curriculum design in theology and development: Human agency and the prophetic role of the church', HTS Teologiese Studies/Theological Studies 72(4), a3432. https://doi.org/10.4102/hts.v72i4.3432

Hankela, E., 2014a, Ubuntu, migration and ministry: Being human in a Johannesburg Church, Brill, Leiden.

Hankela, E., 2014b, “'We're not liberated yet in South Africa." Liberation theology and the concept of humanity in inner-city Johannesburg', Religion and Theology 21(1-2), 173-206. https://doi.org/10.1163/15743012-02101005
Hankela, E., 2014c, 'Faith community as a centre of liberationist praxis in the city' HTS Teologiese Studies/Theological Studies 70(3), Art. \#2768, 9 pp. https://doi. org/10.4102/hts.v70i3.2768

Holland, J. \& Henriot, P., 1983, Social analysis. Linking faith and justice, Orbis Books, Maryknoll, NY

Jennings, W.J., 2011, The Christian imagination. Theology and the origins of race, Yale University Press, New Haven, CT.

Katongole, E., 2010, The sacrifice of Africa. A political theology for Africa, Eerdmans, Grand Rapids, MI.

Klein, J.T., 2001, Transdisciplinarity: Joint problem-solving among science, technology, and society, Synthesebücher, SPP Environment, Basel.

Kretzmann, J.P., 2010, 'Asset-based strategies for building resilient communities', in J.W. Reich, A. Zautra \& J.S. Hall (eds.), Handbook of adult resilience, pp. 484-495, Guilford Press, New York.

Kretzmann, J.P. \& McKnight, J.L, 1993, Building communities from the inside out: A path toward finding and mobilizing a community's assets, ACTA, Chicago, IL.

Kritzinger, J.N.J., 1991, 'Re-evangelising the white church', Journal of Theology for Southern Africa 76, 106-116.

Landman, C., 2013, 'Theological education in South Africa', in I.A. Phiri \& W. Werner (eds.), Handbook of theological education in Africa, pp. 239-245, Cluster, Pietermaritzburg.

Lombaard, C., 1999, 'Kontekstuele prediking met behulp van kommentaarjoernalistiek', in C. Lombaard (ed.), "... in die wêreld..." Vyf bydraes tot kontekstuele prediking, pp. 22-46, Department of Latin and Greek, Rand Afrikaans University, Johannesburg.

Lombaard, C., 2016, 'Theological education, considered from South Africa: Current issues for cross-contextual comparison', HTS Teologiese Studies/Theological Studies 72(1), Art. \#2851, 5 pp. https://doi.org/10.4102/hts.v72i1.2851

Maimela, S.S. \& Hopkins, D.N., 2017, We are one voice. Black theology in the USA and South Africa, Wipf \& Stock, Eugene, OR.

Meylahn, J-A., 2016, 'The unbearable lightness of différance: The ethos of deconstruction', Verbum et Ecclesia 37(1), a1658. https://doi.org/10.4102/ ve.v37i1.1658

Mofokeng, T., 1983, The crucified among the cross-bearers, Uitgeversmaatschappij J.H. Kok, Kampen.

Mugambi, J.N.K., 1995, From liberation to reconstruction. African Christian Theology after the Cold War, East African Educational, Nairobi.

Naidoo, M., 2008, 'The call for spiritual formation in Protestant theological institutions in South Africa', Acta Theologica (Suppl. 11), 28, 128-146.

Naidoo, M., 2015, 'Ministerial formation and practical theology in South Africa', International Journal of Practical Theology 19(1), 164-188, https://doi. org/10.1515/ijpt-2015-0004

Nel, R.W., 2011, 'Postcolonial missiology in the face of empire: In dialogue with Frantz Fanon and Steve Bantu Biko', Studia Historiae Ecclesiasticae 37, 157-170.

Nel, R.W, 2016, 'Children must be seen and heard': Doing postcolonial theology with children in a (southern) African Reformed Church, HTS Teologiese Studies/
Theological Studies 72(1), 2016. https://doi.org/10.4102/hts.v72i1.3565

New York Theological Seminary, 2012, Academic programs, viewed 15 May 2019 from http://www.nyts.edu/prospective-students/academic-programs/.

Northern Seminary, 2019, Academic programs, viewed 15 April 2019, from https:// www.seminary.edu/programs/.

Pilario, D.F., 2005, Back to the rough grounds of Praxis: Exploring theological method with Pierre Bourdie', Peeters, Leuven.

Pittsburgh Theological Seminary, n.d., Master's degrees, viewed 15 April 2019, from https://www.pts.edu/Master-s-Degrees.

Sands, J., 2018, 'Introducing cardinal Cardijn's See-Judge-Act as an interdisciplinary method to move theory into practice', Religions 9(4), 129. https://doi. org/10.3390/rel9040129

Tracy, D., 1981, The analogical imagination: Christian theology and the culture of pluralism, Crossroads, New York.

University of Kwazulu-Natal (UKZN), 2019 a, viewed 18 September 2019, from http:// ujamaa.ukzn.ac.za/Homepage.aspx.

University of Kwazulu-Natal (UKZN), 2019b, viewed 18 September 2019, from https:// srpc.ukzn.ac.za/staff-profile/religion/charlene-van-der-walt/.

University of South Africa (UNISA), 2017, viewed 18 September 2019, from https:// www.unisa.ac.za/sites/corporate/default/Colleges/Human-Sciences/Schools, departments,-centres,-institutes-\&-units/School-of-Humanities/Department-ofBiblical-and-Ancient-Studies.

University of South Africa (UNISA), 2018, viewed 18 September 2019, from https:// www.unisa.ac.za/sites/corporate/default/Colleges/Human-Sciences/Schools, departments,-centres,-institutes-\&-units/School-of-Humanities/Department-ofChristian-Spirituality,-Church-History-and-Missiology.

University of South Africa (UNISA), 2019, viewed 18 September 2019, from https:// www.unisa.ac.za/sites/corporate/default/Colleges/Human-Sciences/Schools, departments,-centres,-institutes-\&-units/School-of-Humanities/Department-ofPhilosophy,-Practical\%C2\%AOand-Systematic-Theology.

The Kairos Theologians, 1986, The Kairos document: challenge to the church: a theological comment on the political crisis in South Africa, Skotaville Publishers, Braamfontein.

Vellem, V., 2007, 'The symbol of liberation in South African public life: A black theological perspective', PhD thesis, University of Pretoria, Pretoria. 
Vellem, V., 2015a, 'Black theology of liberation and radical democracy: A dialogue', Scriptura 114, 1-13. https://doi.org/10.7833/114-0-1111

Vellem, V., 2015b, 'Black theology of liberation: A theology of life in the context of Empire', Verbum et Ecclesia 36(3), Art. \#1470, 6 pages. https://doi.org/10.4102/ ve.v36i3.1470

Vellem, V.S., 2015c, 'Unshackling the church', HTS Teologiese Studies/Theological Studies 71(3), Art. \#3119, 5 pages. https://doi.org/10.4102/hts.v71i3.3119

Venter, R., 2013, 'Speaking God at a public university in South Africa: The challenge of epistemological transformation', Studia Historia Ecclesiasticae 39(Suppl. 1).

Venter, R., 2016, 'Theology and the (post-)apartheid university: Mapping discourses, interrogating transformation', Transformation in Higher Education 1(1), a5. https://doi.org/10.4102/the.v1i1.5

VID Specialized University, n.d., Studies, viewed 15 May 2019, from https://www.vid. no/en/studies/.
Volf, M., 2015, Flourishing: Why we need religion in a globalised world, Yale University Press, New Haven, CT.

West, G.O., 1993, Contextual Bible study, Cluster Publications, Pietermaritzburg.

West, G.O., 1995, Biblical hermeneutics of liberation: Modes of reading the Bible in the South African Context, Orbis Books, Maryknoll, NY.

West, G.O., 1999, Academy of the poor: Towards a dialogical reading of the Bible Sheffield Academic Press, Sheffield

West, G., 2013, 'The School of Religion, Philosophy and Classics: Doing contextual theology in Africa in the University of KwaZulu-Natal', in I.A. Phiri \& D. Werner (eds.), Handbook of theological education in Africa, pp. 919-926, Cluster Publications, Pietermaritzburg.

Wethmar, C., 2001, 'Theological education in an ecumenical context: Principles and procedures of the Pretoria model', Verbum et Ecclesia/Skrif en Kerk 21(2), a1268. https://doi.org/10.4102/ve.v21i2.1268 